原著

\title{
消化器外科手術を受けた患者の個別的背景における 術後疼痛の経時的変化
}

Trajectories of postoperative pain after gastroenterological surgery differ by patient's individuality and surgical characteristics

$\begin{array}{lcc}\text { 井川由貴 } & \text { 遠藤みどり } & \text { 山本奈央 } \\ \text { Yuki Igawa } & \text { Midori Endo } & \text { Nao Yamamoto }\end{array}$

\begin{abstract}
【研究目的】個別的かつ予測的な苦痛緩和への示唆を得るために術後疼痛の経時的变化と個人特性に よる影響を明らかにした。

【研究方法】開腹術目的で消化器外科に入院した患者 47 名の患者特性と手術特性を説明变数, 術直 後から翌日就眠時までの 8 時点の疼痛スケール (NRS) を目的变数とする多变量解析を行った.

【結果】対象者は, 女性 20 名 (42.6\%), 男性 27 名 (57.4\%), 平均年齢 67.4 歳, 33 人 (70.2\%) に同居者がおり, 半数以上に術後のリスク要因があった. 平均手術時間は 213.6 分, 14 名 (29.8\%) が通常より多い術後ルートが長期間㨂入された，術後 4 時間が疼痛のピークで $(p=0.0083), 65$ 歳未満 $(p=0.0771)$, 独居者 $(p=0.047)$, 手術時間の延長 $(p=0.0219)$, 術後儿一ト類が多 い患者 $(p=0.0722)$ の術後疼痛が強い傾向にあった.

【考察】個別的な術前情報が術後疼痛に影響することを意識したかかわりが術後疼痛への予測的アプ ローチには重要である.
\end{abstract}

キーワード : 術後疼痛の経過, 消化器外科手術患者, 患者の個別性, 手術特性, マルチレベルモデル

Key Words : trajectory of postoperative pain, patients under digestive surgery, patient's individuality, surgical characteristics, multilevel analysis

\section{I . 研究背景}

近年, 周術期医療に押いて, 患者の術後早期回復と 日常生活の再獲得を支援するため, 北欧から発信され た術後回復力強化プログラム (enhanced recovery after surgery；ERAS）（Fearon et al, 2005）が普及している. ERAS は術後回復に関してエビデンスのある介入を一 つひとつ検証し組み合わせたもので, 従来必須であっ た麻醉前投薬や術後経鼻胃管, ドレーン留置等を必要 最低限とし, 低侵襲手術の実施, 徹底した疼痛管理, 早期離床，早期経腸栄養等をプログラムに含む. ERAS の普及は，包括医療の推進や先進医療技術の高
度化とも相まって在院日数を著しく短縮させ， 2002 年に 21.2 日（厚生労働省, 2002）だった開腹術後の 在院日数は 2011 年には 15.2 日（厚生労働省, 2011） となり，現在はさらに短縮の途にある。また早期退院 を目指すこの流れは, 術後患者の日常生活への早期復 帰だけでなく, 術後合併症の格段の減少 (Spanjersberg et al, 2011）と, 超高齢社会の到来で増加する患者へ の平等な医療提供や高騰する医療費の減額対策にも貢 献している（Roulin et al, 2013).

一方, 看護に扔いては, 在院日数短縮に伴う入退院 患者数と看護業務の増加, 患者の高齢化と多様化およ び基礎疾患合併患者の増加等に対応すべく専門分化し たマニュアルやガイドラインの遵守徹底にかかる膨大 
な時間などから，周術期の各時期に応じた看護展開が 困難な状況がうかがえる。一般的に周術期看護を担う 看護師は，術後傷害期から回復期までの各期の身体状 況や侵襲への生体反応の経時的変化に応じた看護を展 開している，例えば，循環動態や呼吸・代謝機能が不 安定な手術直後は, 手術侵襲や急性疼痛が合併症に移 行しないように異常の早期発見と早期対応に重点を置 き（福田美和子，2007）, その後は, 患者の回復意欲 に応じて徐々に身体諸機能の自立を促し，社会復帰へ の自己効力感を高められるようかかわるのが一般的で ある（柴・松田，2014）。術後回復の質を評価した研 究では, 術後回復を評価する5つの要素（安楽, 感情, 身体機能，心理的支援，疼痛）がそれぞれ異なる夕イ ミングで回復することを報告しており（Shida et al, 2015)，術後経過の時期に応じた適切な看護介入が必 要であることを示している. しかし, 平均在院日数が 短縮化するなかで，患者への術前教育が不十分なまま 手術を迎えるケースや，経時的に変化する術後疼痛ア セスメントが十分行えないケースもあり，在院日数短 縮は患者の早期社会復帰をかなえる一方, 術後患者へ の適切な回復支援や個別的かかわりの未充足につなが る可能性がある（高島・五木田，2009）.

患者にとってより良い周術期とは, 安心して手術に 臨み, 術後の痛みや合併症がなく順調な回復経過をた どり，失った機能を早期に回復あるいは代替的に調整 して社会復帰できることであり（Sasaki・Tamakoshi, 2018)，その実現のためには，在院日数が短縮するな かでも術後回復状況を適切に評価し，その回復状況に 合わせた看護を実践することが重要である．とくに一 時的な症状として軽視されやすい術後疼痛は, 発生機 序や原因が明確で一時期を過ぎれば軽快することが特 徵であるが, 術後の変動が著しく, それ自体が患者に とって不快であること, 術後の異常徴候の重大なサイ ンになり得ることから, 術後の経時的変化を観察しそ の変化に応じた適切な介入が必要である. しかし, 術 後疼痛の経過は患者の個別性によるところが大きく， 疾患や創部・ドレーン挿入部などの手術特性だけでな く，年齢や過去の手術体験など患者の個人特性にも大 きく左右され (Chapman et al, 2012), 手術特性や個 人特性等によって術後疼痛の経過がどのように変化す るのか十分な検証がされているとはいえない (Kannampallil et al, 2016/井川ら, 2013).さらに近 年の在院日数短縮のなかにおいて，個別的な情報聴取
や慎重なアセスメントによって，適切なタイミングで かかわることも容易なことではない.

そこで本研究では, 経時的に変化する術後疼痛の経 過を明らかにし，患者の個人特性や手術状況によって 異なる軌跡をたどる術後疼痛に対する看護への示唆を 得たいと考えた. 在院日数が短くなり, 患者の術後早 期社会復帰が実現できるようになった昨今，患者の個 別性や術後の時間経過によって異なる術後疼痛の経過 を把握することは，時期に応じて異なる術後患者への 予測的かつ個別的なケアへの示唆を得ることになり， 手術を受ける患者への一層の苦痛緩和を推進する一助 になると考える。

\section{II. 研究目的}

手術を受ける患者の術後疼痛の経時的変化を明らか にし，患者の個人特性および手術特性が，術後疼痛の 経過にどう影響するかを明らかにすることを本研究の 目的とする.

\section{III. 研究方法}

\section{1. 研究デザイン}

後乃向き縦断研究

\section{2. 調査対象}

$\mathrm{A}$ 病院の消化器外科病棟に手術目的で入院した患者 50 名の診療録を分析対象とした．診療録の閲覧対象 となる患者は, 全身麻酔下で消化器疾患にて開腹手術 を受けた患者で, 退院日が確定しており本研究への協 力同意が得られる患者とした。 また予定入院患者を調 査対象とし, 緊急入院, 夜間入院, 集中治療室管理に て術後の循環・呼吸管理が必要である患者，手術直後 の麻酔覚醒が良好でない患者, および認知機能上, 研 究の趣旨に理解が得られない患者, 研究の趣旨説明を 受けることが病状的に負担となる患者，未成年者は調 查対象から除外した。

\section{3. 調查期間}

2015 年 12 月～ 2016 年 2 月

\section{4. デー夕収集方法}

調查期間中に A 病院の消化器外科病棟に手術目的 
で入院した患者のうち, 手術終了後の状態が安定し退 院日が確定した患者に，口頭抒よび文書にて本研究の 趣旨, 方法, 倫理的配慮について説明し, 退院までの 間に調查協力への同意書を提出してもらうょう依頼し た．同意書の提出があった患者の退院後に診療録を閲 覧しデータ収集を行った．診療録からは，術後疼痛の 経過に関連する以下の情報を収集した.

\section{5. 調査内容}

\section{1）患者の基本情報}

性別，年齢，同居家族の有無，入院時の身体計測值 (血圧, 脈拍, 体温, $\mathrm{SPO}_{2}$, 身長, 体重 $\mathrm{BMI}$ ), 術前 検查等において術後合併症のリスクとなり得る要因の 有無（腰・下肢の痛みやしびれ，不整脈，糖尿病の既 往，貧血状況，腎機能・呼吸機能・心機能の低下，高 血圧), 入院日数

\section{2）手術・疾患に関する情報}

手術疾患, 術式, 手術時間, 麻酔時間, 術中出血量, 創部位，術中体位

\section{3）術後の身体状況に関する情報}

術後の離床状況, 術後の血液デー夕 $(\mathrm{Hb}, \mathrm{Ht}$, $\mathrm{TP}, \mathrm{Alb}, \mathrm{CRP}, \mathrm{WBC}$, 血糖值, $\mathrm{SPO}_{2}$ ), 術後のルー 卜類の有無と種類

\section{4）術後疼痛・鎮痛に関連した情報}

術後帰室直後から翌日就眠時までの 8 時点（帰室直 後 1 時間前後 -4 時間後 -8 時間後 - 翌早朝 - 午前 午後〜夕方・就眠時) における疼痛スケール (Numerous Rating Scale；NRS）の值, 術後鎮痛に関する情報につ いてデー夕を収集する，術後疼痛の評価には，行動面 や心理, 生理的反応などから痛みを測定評価できる多 くのスケール (Payen et al, 2001 / Maruo et al, 2013 ／Cleeland・Ryan, 1994）があるが，本研究では，簡 易で汎用性が高く, 患者の術後疼痛を主観的かつ包括 的にとらえるNRS を用いた。

\section{6. 分析方法}

\section{1）目的変数と説明変数}

\section{(1) 目的変数}

本研究では, 看護師が記載した患者の診療記録から 得られたデー夕のうち, 術後帰室直後から翌日就眠時
までの 8 時点の術後疼痛（NRS）の值を患者個人の繰 り返しデータである目的変数とした。

\section{(2) 説明変数}

本研究では, 患者の基本情報, 手術・疾患に関する 患者情報, 術後の身体状況に関する情報をそれぞれ説 明変数とした，その際，術前検查等にて測定された結 果を基に，腰・下肢の痛みやしびれ，血液検査デー夕 (BUN $>20 \mathrm{mg} / \mathrm{dL}, \mathrm{Cr}>1.0 \mathrm{mg} / \mathrm{dL}$, 血清総蛋白 $<6.5 \mathrm{~g} /$ $\mathrm{dL}$, 血清アルブミン值 $<3.7 \mathrm{~g} / \mathrm{dL}$ ), 呼吸機能検査 $\left(\mathrm{FEV}^{1.0 \%}<70 \%, \% \mathrm{VC}<80 \%\right)$, 心臟超音波検査（EF $<50 \%)$, 収縮期血圧 $>140 \mathrm{mmHg}$ または拡張期血圧> $90 \mathrm{mmHg}$, 不整脈, 糖尿病の既往のうち, いずれかを 有する患者は, 術後りスク要因ありとして分析を行っ た．また手術に関する情報のうち，対象者の疾患別の 平均手術時間を基準に手術時間が長い群と短い群を設 定した，術中出血量については，対象者の性別および 疾患別の平均術中出血量によって, 出血量の多い群と 少ない群を設定した．さらに, 術後の身体状況のうち, 術後のルート類の有無に関しては, 膀胱留置カテーテ ル，心電図モニター，手術翌日抜去の胃管扔よび酸素 マスクまたは鼻腔カニューレ, 末梢静脈内点滴ルート, 腹脭内ドレーン 1 本以内, 硬膜外 PCA カテーテルの 挿入患者を通常ルート装着群とし，腹腔内ドレーン 2 本以上, 中心静脈カテーテル, 手術翌日以降も継続す る胃管留置および酸素マスクまたは鼻堔カニューレを 装着している患者を複数ルート装着群とした.

\section{2）分析手法亡分析手順}

まず対象者の基本属性について記述統計量を示し た. 次に, 患者の術後 8 時点の術後疼痛 (NRS) の值 を目的変数, 患者の基本情報, 手術・疾患に関する患 者情報, 術後の身体状況に関する情報を説明変数とし たマルチレベルモデル（一般線形混合モデル）による 多変量解析を行い, 各測定時点に扔ける術後疼痛の值 と傾きの推定值を算出して一般化モデルとしてグラフ 化した (Suzuki et al, 2015). この分析手法は, 本研究 のように分析したい項目（本研究では術後疼痛）が各 個人という特定サンプル内にあり種々の個人状況が同 一個人の術後疼痛に影響する場合や，個人データが経 時的に繰り返し測定される階層性のあるデータ分析の 場合，および測定時点にばらつきがあるデー夕分析の 場合に利用価値が高いとされ (Douglas，2004), 導き 出される結果は調査対象者の現況を示すものではない 
が, 各説明変数の影響による目的変数の推定值と傾き を算出しその経過をモデル化することができるため, 本研究のデー夕のような場合, その時点の NRS と時 間経過に伴う変化をグラフ化して視覚的に把握するこ とができる．また本研究のように，患者個人の疼痛経 過が，患者が遭遇する種々の条件（手術・疾患に関す る患者情報，術後の身体状況など）から影響を受ける と考えられる場合, 分析結果には個人による影響と周 囲条件による影響とが混在し，単層的デー夕を想定し た従来の重回帰分析等の手法では正しい結果を導けな い可能性がある (Hox・Kreft, 1994 / Twisk, 2006). さらに, 説明変数の影響を分析する際には, 男性, 女 性等のようにその变数の効果が固定される場合（固定 効果）と，患者の個人特性等のようにその効果が変動 すると考えられる場合（変量効果）があるが，マルチ レベル分析は，階層性のあるデータの分析や固定効果 と変量効果が混合したデータの分析が可能な分析手法 である（小野寺ら，2006）.

本研究では, 時間経過による術後疼痛が対象者個人 によって変動することを想定し, 各測定時点の固定効 果を同一個人の繰り返しデータとして分析を行った (repeated analysis)，分析の手順は，まず，術後疼痛の 基本経過となる，個人と術後の時間経過（測定時点） がNRS の值と傾きに影響するモデルを推定し分析を 行った. 次に, 個人と測定時点のほかに, 患者の基本 属性，手術・疾患に関する情報が NRS の経過に影響 するモデルをそれぞれ推定し分析を行った。最後に， 単変数ごとの分析において, 術後疼痛の変動に影響す ると考えられるすべての変数を投入したモデルを推定 し分析を行った．これらのすべての分析において算出 されたNRS の值と傾きをグラフに示した．モデルの 当てはまりの良さの基準には赤池情報量基準 (AIC), シュバルッのベイズ情報量基準（Bayesian information criterion；BIC）を使用し (小野寺ら, 2006), 分析ソ フトは SAS Ver.9.4（Cary，NC，USA）を使用した.

\section{IV．研究における倫理的配慮}

施設管理責任者および対象患者の主治医に入院患者 のデー夕閲覧・使用について承諾を得たのちに, 対象 施設に入院中の患者で術後退院予定が確定した患者 に, 本研究の趣旨, 方法, 倫理的配虑について研究者 が直接口頭と文書にて説明を行った。依頼文書には，
本調査への協力が自由意思に基づくものであり，調査 協力への有無が治療や看護に一切影響しないこと, 知 り得た情報は本研究以外に使用しないこと, 本研究に 関係ないデー夕の閲覧をしないこと，匿名性の保持, 公表の可能性および個人情報の取り扱いについて記載 し，後日，退院前に病棟に設置した提出箱への同意書 提出によって調查協力への同意を得た。説明時間は 10 分程度とした. なお, 本研究は研究者の所属大学 の研究倫理審査委員会 (承認番号：1515), および研 究実施施設の研究倫理審查委員会 (承認番号 : 27-50) の承認を得て実施した。

\section{V. 結果}

\section{1. 調査対象者}

調査対象となる患者 56 人に調査依頼を行い，同意 書の提出にて調查協力の同意が得られた 50 人の診療 記録より術後疼痛に関するデー夕を得た（回収率 89.3\%)。そのうち, 主要デー夕である術後疼痛の程 度（NRS）の記載が「痛みなし」「体動時のみあり」 などのように表記されていた 3 名のデー夕を除外し， 47 名 $(94.0 \%)$ の診療記録からのデー夕を本研究の分 析対象データとした.

\section{2. 対象者の基本属性}

\section{1）患者の基本情報}

対象患者の基本情報を表 1 に示した，患者は，女性 20 名 (42.6\%), 男性 27 名 (57.4\%) で，全体の平均 年齢は $67.4 \pm 14.2$ 歳, 男女とも 65 歳以上 75 歳未満 の前期高齢者が多かった。また男性は $74.1 \%$ ，女性は $65.0 \%$ に同居家族が㧍り，今回以前に手術経験がある と答えたのは全体で $42.6 \%$ あったた，さらに男女とも 半数以上が手術前に何らかのリスク要因を有してい た．その内訳は，歩行困難・腰痛等が 6 名 $(12.8 \%)$, 高血圧が 11 名 $(23.4 \%), \mathrm{BUN} \cdot \mathrm{Cr}$ 值において腎機能 低下がある者が 6 名 $(12.8 \%)$, 糖尿病が 8 名 $(17.0 \%)$, $\mathrm{FEV}^{1.0 \%}$ ・\% VC 低值があり呼吸機能低下とみなせる者 が 7 名 (14.9\%), 不整脈や心疾患のある心機能低下が 9 名 $(19.1 \%), \mathrm{Hb} \cdot \mathrm{Ht}$ 低值による貧血が 5 名 (10.6\%) であった．また平均入院日数は全体で $23.6 \pm 24.1$ 日 で男女差はなく，入院時の血圧，体温，脈拍， $\mathrm{SPO}_{2}$, および身長と体重，BMIの計測值でも，身長と体重 の男女差以外は顕著な差はみられなかった。 
表1 対象者の基本属性 $(n=47)$



数值データは Wilcoxon 検定, 名義データは $\chi^{2}$ 検定を行った

\section{2）手術・疾患に関する情報}

手術・疾患に関する情報を表 2 に示した。手術部 位は 30 名 (63.8\%) が腸疾患（直腸, 結腸, 回盲部等), 7 名 (14.9\%) が胃疾患（全摘出，幽門部切除，噴門 部切除), その他, 肝細胞がん, 膵臟がんなど 10 名 (21.3\%) による開腹術が含まれた。平均麻醉時間は $255.2 \pm 98.3$ 分 (range 75-495), 平均手術時間は $213.6 \pm 93.9$ 分 (range 52-476), 術中出血量は $285.7 \pm$ 289.2mL（range 10-1,200）であったままた，術中体位 は仰臥位が 35 名 $(74.5 \%)$ ともっとも多く, 次いで 載石位 11 名(23.4\%)であった。創部位は 41 名 $(87.2 \%)$
が上中腹部正中創であった.

\section{3）術後の身体状況に関する情報}

術後は 33 名 $(70.2 \%)$ の患者が, 術後通常のルー 卜類が装着されており,残り 14 名 (29.8\%) の患者は, 鎖骨下または頸部からの中心静脈カテーテル，2 本以 上の腹䏶内ドレーン, 手術後翌日以降の酸素継続投与, 胃管継続挿入のいずれかが該当する患者であった．ま た手術翌日中に歩行まで離床が進んだ患者は 35 名 (74.4\%) であり, 残りは歩行可能になるまでに手術 翌々日以降まで時間を要した，手術後翌日の血液検査 
表2 対象患者の手術特性 $(n=47)$

\begin{tabular}{|c|c|c|c|c|c|}
\hline & 全体（n=47） & $\begin{array}{c}\text { 腸切除術（直腸· } \\
\text { 結腸·回盲部 }) \\
(\mathrm{n}=30)\end{array}$ & $\begin{array}{c}\text { 胃切除術 } \\
\text { (全摘·幽門 } \cdot \\
\text { 噴門部) } \\
(n=7) \\
(n=7)\end{array}$ & $\begin{array}{c}\text { その他 (肝· } \\
\text { 膵切除) } \\
(\mathrm{n}=10)\end{array}$ & $p$ \\
\hline $\begin{array}{c}\text { 手術時間1) } \\
\text { (分) }\end{array}$ & $\begin{array}{c}213.6 \pm 93.9 \\
(52-476)\end{array}$ & $\begin{array}{c}198.2 \pm 16.9 \\
\quad(52-476)\end{array}$ & $\begin{array}{c}264.4 \pm 35.1 \\
(184-313)\end{array}$ & $\begin{array}{c}224.2 \pm 29.3 \\
\quad(80-405)\end{array}$ & $0.0798^{2)}$ \\
\hline $\begin{array}{c}\text { 麻酔時間 1) } \\
\text { (分) }\end{array}$ & $\begin{array}{c}255.2 \pm 98.3 \\
(75-495)\end{array}$ & $\begin{array}{c}236.9 \pm 17.6 \\
(75-495)\end{array}$ & $\begin{array}{c}311.4 \pm 36.5 \\
(218-363)\end{array}$ & $\begin{array}{c}270.4 \pm 30.5 \\
\quad(118-447)\end{array}$ & $0.0663^{2)}$ \\
\hline \multirow[t]{2}{*}{$\begin{array}{c}\text { 術中出血量1) } \\
(\mathrm{mL})\end{array}$} & $\begin{array}{c}285.7 \pm 289.2 \\
(10-1,200)\end{array}$ & $\begin{array}{c}268.3 \pm 127.1 \\
(10-1,000)\end{array}$ & $\begin{array}{c}207.9 \pm 264.1 \\
(10-690)\end{array}$ & $\begin{array}{c}392.1 \pm 327.4 \\
(10-1,200)\end{array}$ & $0.4008^{2)}$ \\
\hline & $\mathrm{n} \quad(\%)$ & $(\%)$ & (\%) & $(\%)$ & $p$ \\
\hline
\end{tabular}

術中体位

\begin{tabular}{crrrrrrrrr} 
仰臥位 & 35 & 74.5 & 20 & 57.1 & 6 & 17.1 & 9 & 25.7 & \\
載石位 & 11 & 23.4 & 10 & 90.9 & 1 & 9.1 & 0 & 0.0 & \\
側臥位 & 1 & 2.1 & 0 & 0.0 & 0 & 0.0 & 1 & 100.0 & $0.0831^{3)}$ \\
\hline 創部位 & & & & & & & & & \\
正中創 & 41 & 87.2 & 30 & 73.1 & 7 & 17.1 & 4 & 9.8 & \\
その他 & 6 & 12.8 & 0 & 0.0 & 0 & 0.0 & 6 & 100.0 & $0.0000^{3)}$ \\
\hline
\end{tabular}

1) mean $\pm \mathrm{SD}$ (range)

2) wilcoxon 検定 , いずれも各疾患ごとの比較では有意差なし

3) $\chi^{2}$ 検定 , いずれも各疾患ごとの比較では有意差なし

データを表 3 に記す。手術翌日は，術後侵襲のため， $\mathrm{Hb}, \mathrm{Ht}, \mathrm{TP}, \mathrm{Alb}$ ，いずれも基準值より低值となっ ており，とくに男性より女性が低い值となっていた. CRP, WBC，血糖值はいずれも炎症性に高值となっ ており, $\mathrm{SPO}_{2}$ は酸素投与下で 94 ～98\%台で経過し ていた

\section{3. 術後疼痛管理に関する患者の状況}

調査対象患者は，全員が手術中に留置した硬膜外力 テーテルからディスポーザブルタイプの PCA システ ムを活用し, フェンタニルクエン酸塩（フェンタニ ル®), ロピバカイン塩酸塩水和物（アナペイン $\left.{ }^{\circledR}\right)$, ドロペリドール (ドロレプタン®) を併用投与してい た. 術後の硬膜外カテーテルからの鎮痛投与指示は一 括指示となっており, 全員がベース投与 $3 \mathrm{~mL} / \mathrm{h}$, ボー ラス投与 $3 \mathrm{~mL}$ ，ロックアウトタイム 60 分であった. また患者全員に術後の疼痛時指示が出されており，第
一指示の「PCA プッシュによるボーラス投与」, 第二 指示の「ペンタゾシン（ソセゴン®）静脈内投与また は筋肉内投与」は全員に指示があった. 第三指示とし て「ブプレノルフィン (レペタン®) 静脈内投与」が 9 名 $(19.1 \%)$,「ジクロフェナク (ボルタレン®) 坐 薬投与」が 3 名 $(6.4 \%)$ に出されていた. 術後 24 時 間に PCA 以外の鎮痛薬をレスキューとして使用した 患者は 29 名 $(61.7 \%)$ であった。

\section{4. 患者の術後疼痛の経時的変化}

術後帰室直後から翌日就眠時までの 8 時点の術後疼 痛 (NRS) の経時的変化について, 説明変数ごとの分 析における各時点での NRS 值, 傾きの推定值をもと にグラフ化した結果を図 1〜 4 に示す.

\section{1）患者特性による術後疼痛の経時的変化}

個人の繰り返しデータにおいて時間経過のみを変数 
表3 手術翌日の血液検査および測定データ $(n=47)$

\begin{tabular}{|c|c|c|c|c|c|}
\hline & & \multirow{2}{*}{$\begin{array}{l}\text { 全体 }(n=47) \\
\text { mean } \pm \text { SD }\end{array}$} & \multirow{2}{*}{$\begin{array}{l}\text { 女性 }(n=20) \\
\text { mean } \pm \text { SD }\end{array}$} & \multirow{2}{*}{$\begin{array}{l}\text { 男性（n=27） } \\
\text { mean } \pm S D\end{array}$} & \multirow{2}{*}{$p^{1)}$} \\
\hline & & & & & \\
\hline Hb (ヘモグロビン值) & $\mathrm{g} / \mathrm{dL}$ & $11.9 \pm 1.6$ & $11.2 \pm 0.3$ & $12.4 \pm 0.3$ & 0.0129 \\
\hline Ht (ヘマトクリット值) & $\%$ & $36.2 \pm 4.6$ & $34.4 \pm 4.1$ & $37.5 \pm 4.5$ & 0.0141 \\
\hline TP（血清総蛋白値） & $\mathrm{g} / \mathrm{dL}$ & $5.4 \pm 0.7$ & $5.1 \pm 0.1$ & $5.5 \pm 0.1$ & 0.0263 \\
\hline Alb (血清アルブミン值) & $\mathrm{g} / \mathrm{dL}$ & $3.1 \pm 0.5$ & $3.0 \pm 0.4$ & $3.2 \pm 0.5$ & 0.1952 \\
\hline CRP & $\mathrm{mg} / \mathrm{dL}$ & $10.3 \pm 7.9$ & $11.4 \pm 9.9$ & $9.5 \pm 6.0$ & 0.6056 \\
\hline WBC (白血球数) & $\times 10^{3} / \mu \mathrm{L}$ & $11.5 \pm 3.5$ & $12.1 \pm 3.5$ & $11.2 \pm 3.6$ & 0.3437 \\
\hline BS（血糖値） & $\mathrm{mg} / \mathrm{dL}$ & $139.8 \pm 38.7$ & $137.6 \pm 38.2$ & $141.5 \pm 39.7$ & 0.755 \\
\hline $\mathrm{SPO}_{2}$ の平均值 ${ }^{2)}$ & $\%$ & $96.7 \pm 1.2$ & $96.7 \pm 1.4$ & $96.8 \pm 1.1$ & 0.8095 \\
\hline
\end{tabular}

1) Wilcoxon 検定, ${ }^{2)}$ 個人の $\mathrm{SPO}_{2}$ の平均

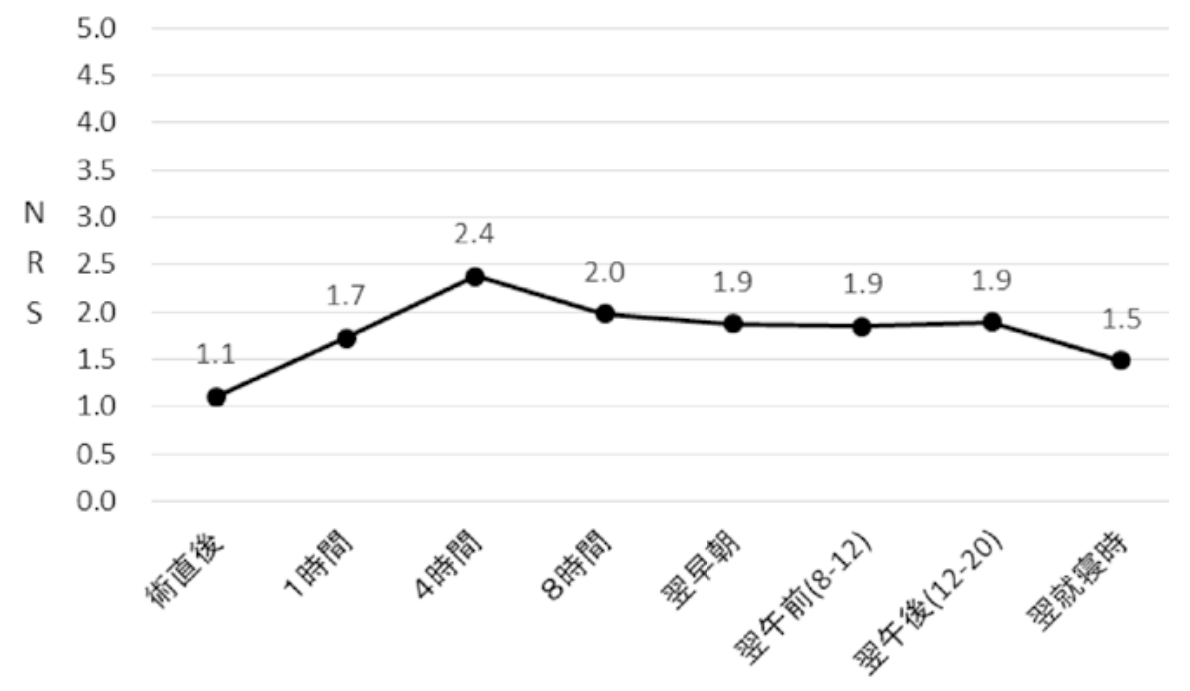

図1 術後疼痛の経時的変化

としたモデルでは, 患者は術後 4 時間経過した時点を 痛みのピークとして, その後も痛みが継続していた(図 1).

患者の年齢を 65 歳未満, 65 歳以上 75 歳未満（前 期高齢者), 75 歳以上 (後期高齢者) の 3 群に分け NRS の変化を見た結果, 65 歳未満群の NRS はほかに 比べ高值傾向にあり $(p=0.0771)$, 比較的若い患者 のほうが, 術後疼痛が強い傾向がみられた（図 2).

術後リスク要因の有無別に見た結果では, 術前に運
動機能, 腎機能, 呼吸機能, 循環機能, 栄養状態のい ずれかの機能低下を有する患者は，それらを有さない 患者と比較してNRS の変化に統計的な違いはみられ なかった（ $p=0.1001 \sim 0.7702 ）$ (図 3).

また同居家族のいない患者は, 術後 1 時間から術後 疼痛のピークである術後 4 時間にかけて，同居家族の いる患者に比べて有意に痛みが強く $(p=0.047)$, そ の後も NRS 高值の状態が継続する傾向が示された(図 4). な押, 患者の性別, 過去の手術歴の有無, 術前 




図2 年齢別の術後疼痛の経時的変化

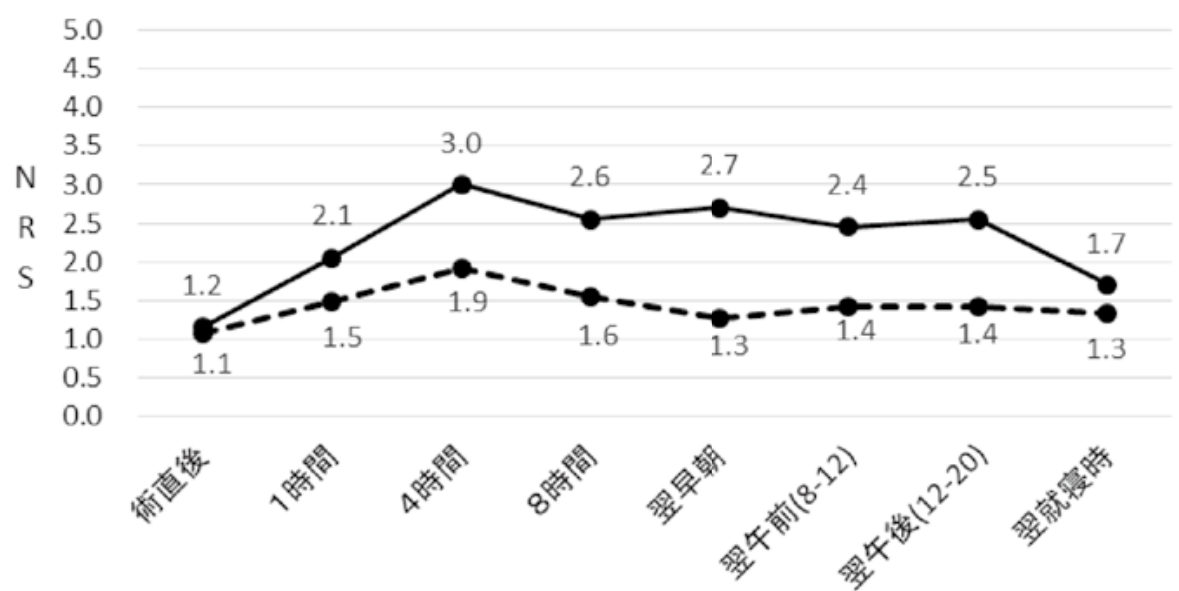

——術後リスクあり -ーー・術後リスクなし

図3術後リスクの有無による術後疼痛の経時的変化

の身体状態（血圧, 脈拍, 体温, $\left.\mathrm{SPO}_{2}, \mathrm{BMI}\right)$ によ る NRS の変化に違いはみられなかった.

\section{2）疾患・手術による術後疼痛の経時的変化}

患者の疾患別に見た結果では, 胃・その他の疾患（肝 蔵がん, 膵蔵がん等) に比べ, 腸疾患患者の NRS が 全時点で高い傾向にあり，とくに術後 1 ～ 4 時間まで の疼痛は有意に増加することが示された $(p=0.0344)$
(図 5).

また手術時間による術後疼痛の経過では, 手術時間 が長い患者は, 帰室後 1 ～時間までに急激に疼痛が 強くなり $(p=0.0219)$, その後も NRS が有意に高く 経過することが示された（ $p=0.0425 ）$ (図 6). また 術中出血量による疼痛経過の比較では, 術中出血量の 多い患者のほうが手術翌日の午前中に NRS が高くな る傾向が示されたが $(p=0.062)$, 全時点で有意な結 


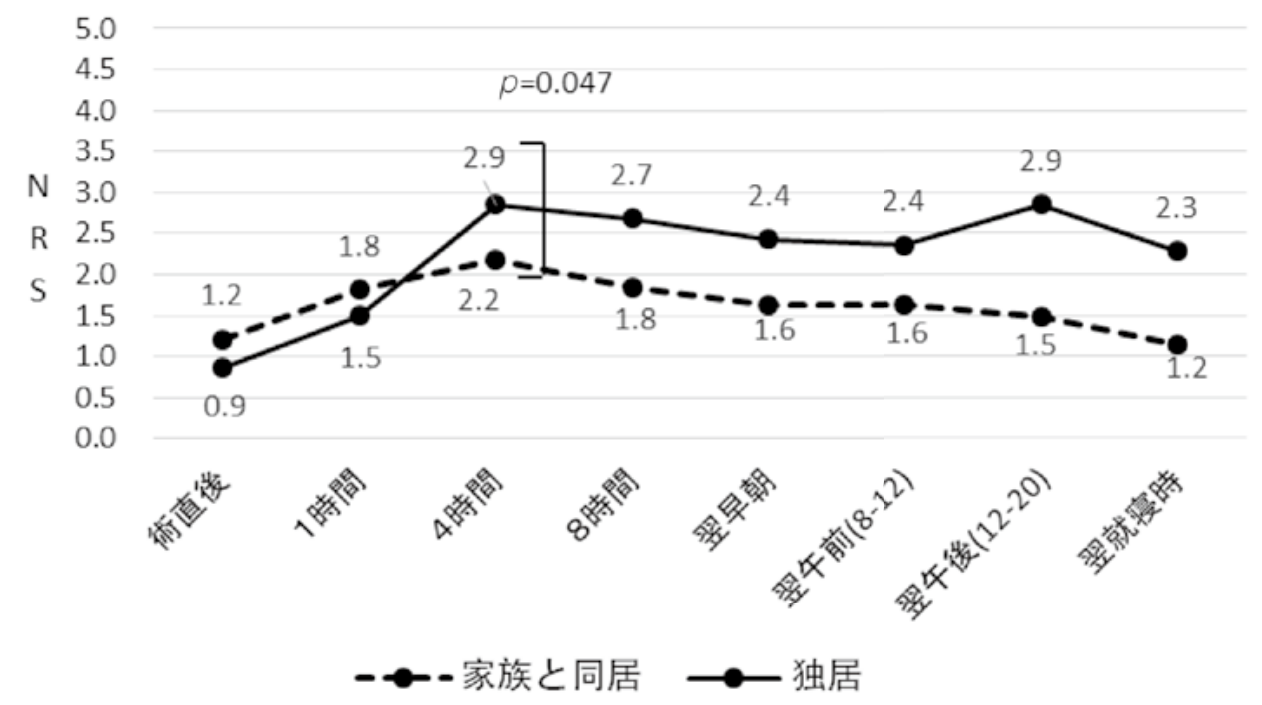

図4 同居家族の有無による術後疼痛の経時的変化

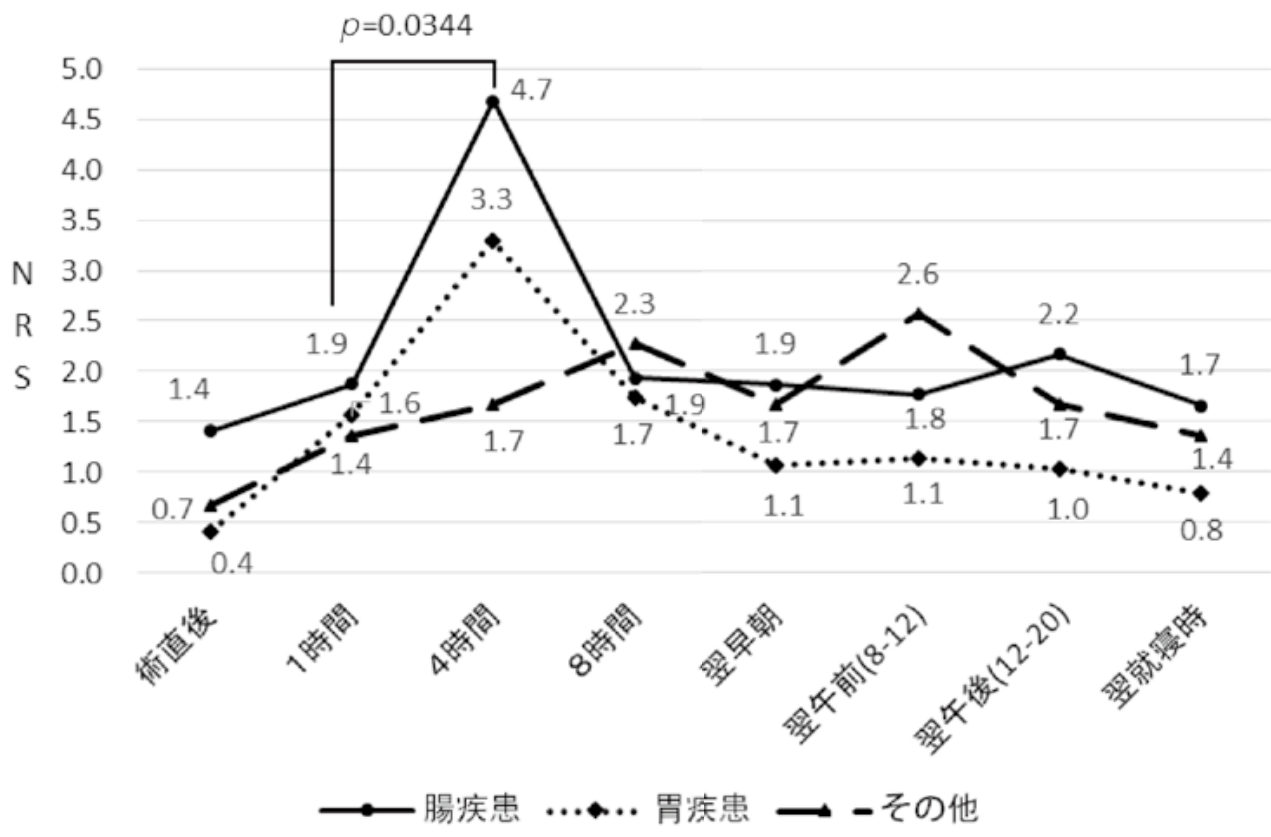

図5 疾患別の術後疼痛の経時的変化

果は得られなかった $(p=0.1692)$ (図 7).

\section{3）術後の身体状況による術後疼痛の経時的変化}

術後のルート類として，2 本以上のドレーンや中心 静脈カテーテルの挿入, 手術翌日以降の酸素投与や胃 管挿入の継続がある患者のほうが，全時点を通して
NRS が高い傾向にあり，とくに手術翌朝は両者の差 が大きくなるが $(p=0.0722)$, 有意な差ではなかっ た（図 8).

また術後は，医師より全患者にPCA ボーラス投与 とそれ以外の疼痛時指示が出されていたが, PCA 以 外の鎮痛薬を使用した患者は明らかにNRS 高值で経 


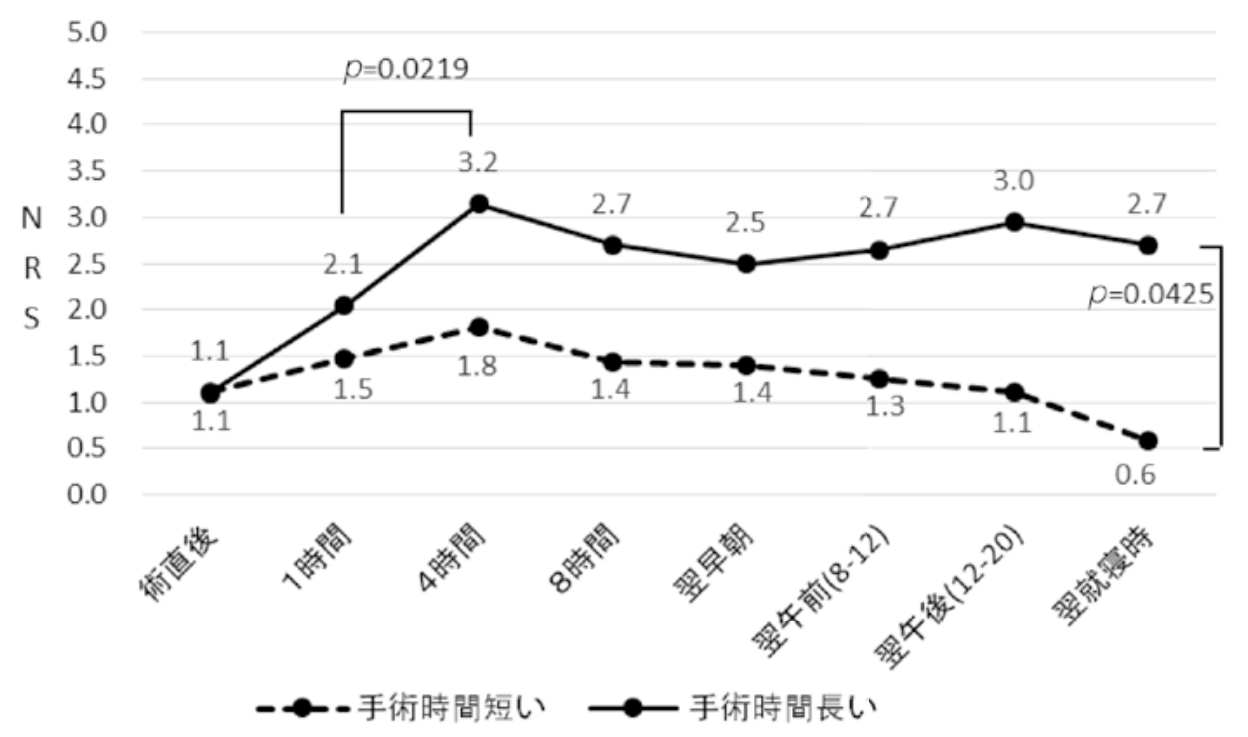

図6 手術時間による術後疼痛の経時的変化

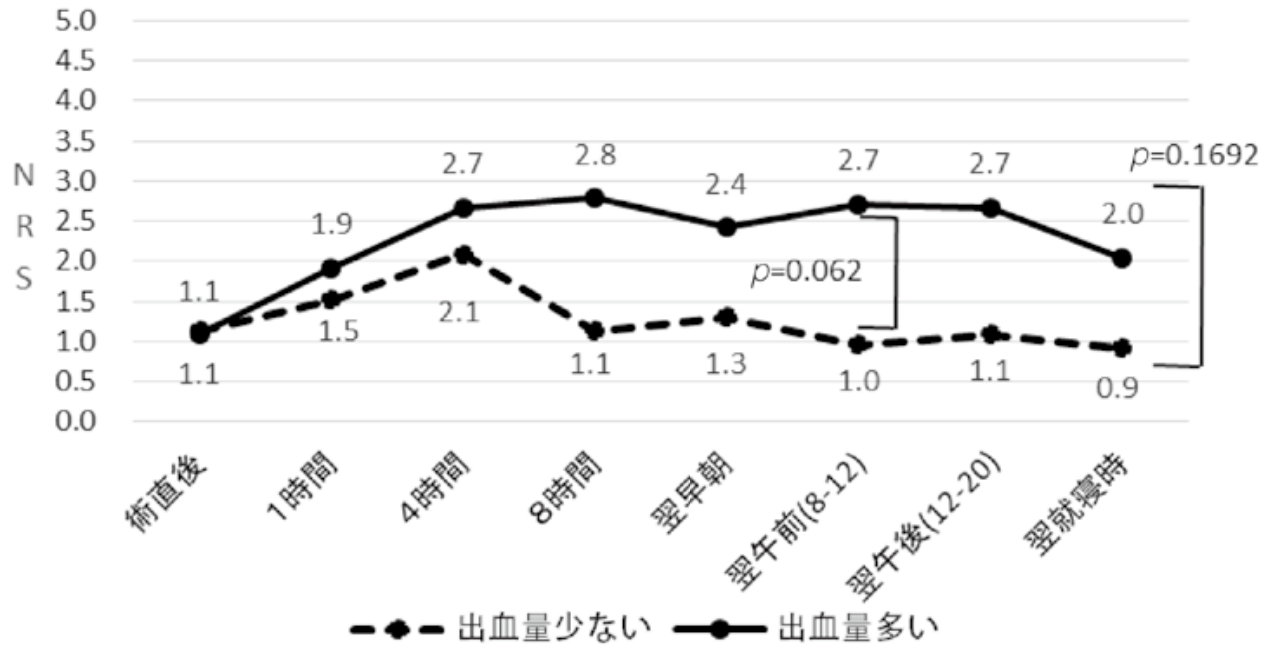

図7 出血量による術後疼痛の経時的変化

過しており $(p=0.0239 ）$ (図 9), 術後疼痛を訴える 患者と痛みが軽度で経過する患者との NRS の差は明 らかであった。

なお，術後翌日の血液デー夕 $(\mathrm{Hb}, \mathrm{Ht}, \mathrm{TP}, \mathrm{Alb}$, $\mathrm{CRP}, \mathrm{WBC}$, 血糖值), 手術翌日の離床状況の違いに よるNRS の経過に差はみられなかった。

\section{5. 術後疼痛 $(N R S)$ への影響要因}

以上の結果から, 患者の年齢, 同居家族の有無, 手
術時間の延長, ルート類の数が NRS 高值で経過する 要因になり得ることが確認できた。 また，術後リスク 要因の有無については統計的に有意な結果ではなかっ たが, 多変量解析の段階で術後疼痛の変動要因となる 可能性を考慮し，これらの変数を投入した分析を行っ た.しかし「年齢」と「手術時間」による影響以外の 特徴が確認できなかったため, 他の変数の影響を明ら かにするために，患者年齢，手術時間が等しいモデル を設定し患者の年齢，手術時間の影響が出ないように 


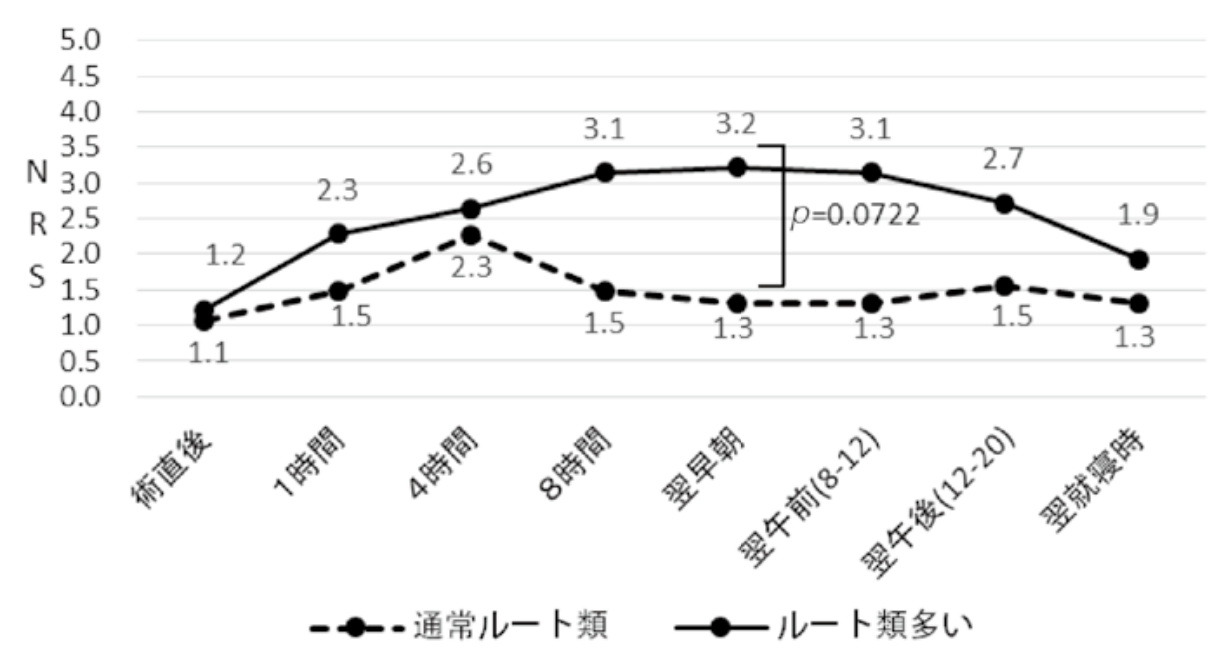

図8 ルート類の数による術後疼痛の経時的变化

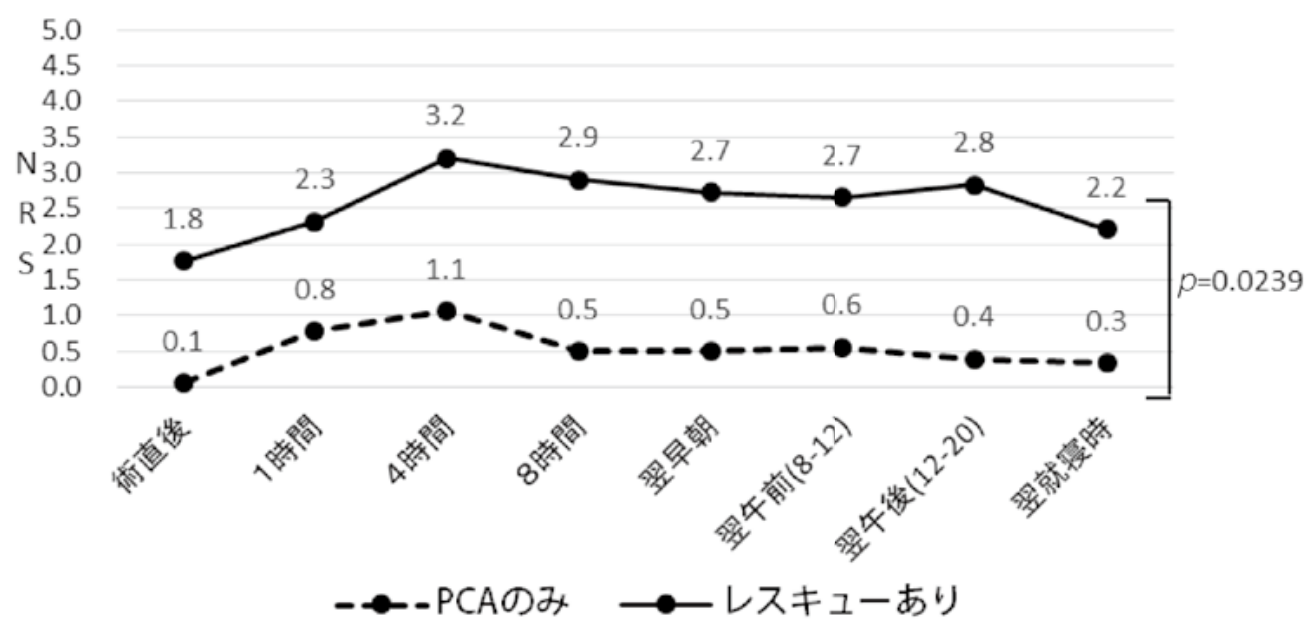

図9 PCA以外のレスキュー使用の有無による術後疼痛の経時的变化

調整したうえで, 同居家族の有無, 術後リスク要因の 有無, 術後ルート類の数による術後疼痛の経過をモデ ル化した（図 10）。術後 PCA 以外のレスキュー使用 の有無については, 術後疼痛の予測要因になり得ない ため変数には含めなかった.

分析の結果, 術後 4 時間の疼痛増強をピークとして ( $p=0.0083)$, 挿入ルートの数によって, 術後 $4 \sim 8$ 時間の間に一度軽減するパターンと, ピーク後も軽減 せずに経過するパターンがあること，また，ルートが 多い患者のほうが術後翌日の午前の疼痛が強いという 統計的に有意な傾向があることが示された $(p=$
0.0544)。また，どちらのパターンにおいても，術後 リスク要因がなく同居家族のいる患者は，全時点にお いて術後疼痛が低いまま経過する傾向が示された，と くに, 術後疼痛がピークとなる術後 $1 \sim 4$ 時間の間の 疼痛上昇の傾きは独居者のほうが有意に大きかった ( $p=0.0436)$. さらに通常ルート群に扔いては, 独居 患者の場合には，一度軽減した術後疼痛が翌日の午後 に再度上昇する二層性の疼痛パターンがみられるのに 対し, 同居者のいる患者では翌日午後の疼痛上昇がみ られなかった。 


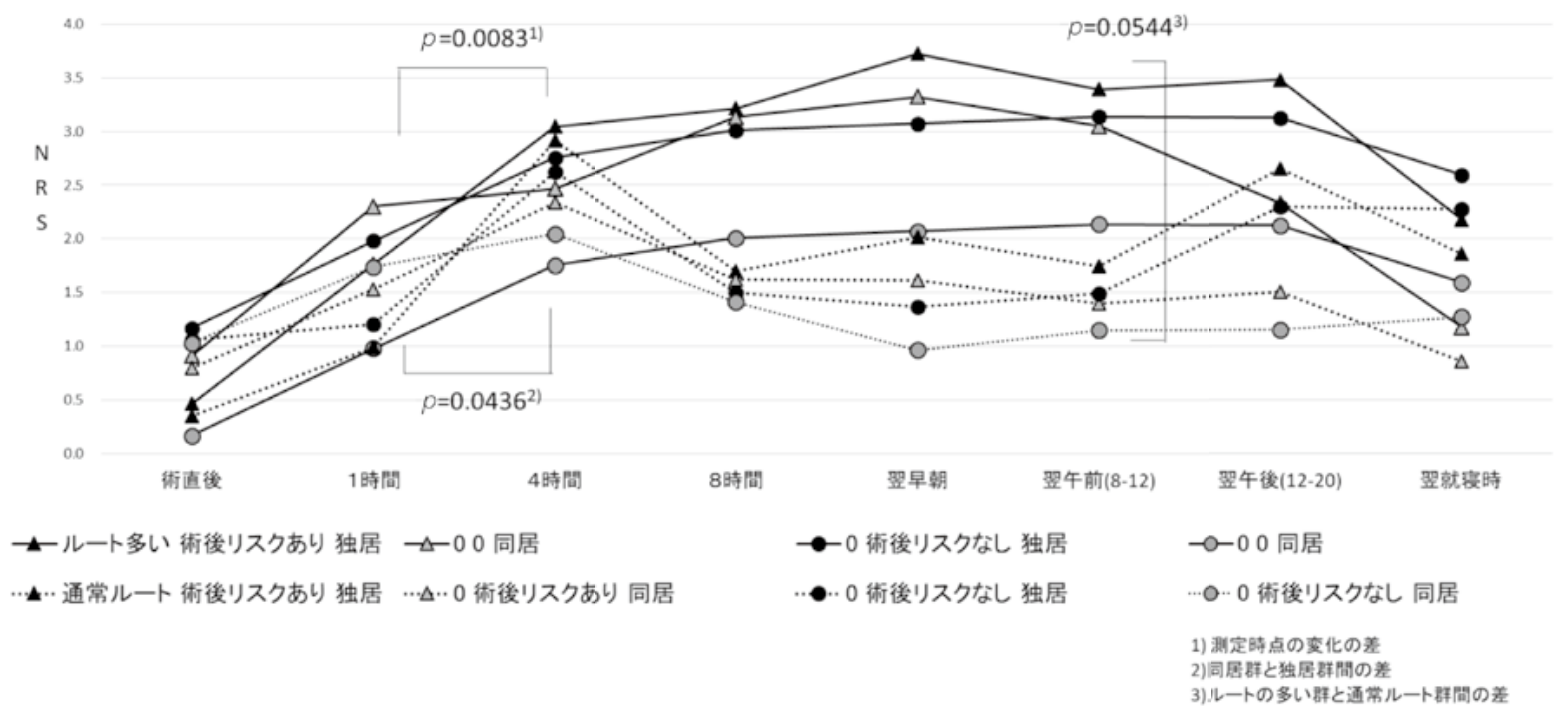

図10 術後リスク, 同居, 術後ルート類ごとに見た経時的変化 $*$ 年齢・手術時間は調整ずみ

\section{VI. 考察}

本研究では, 消化器外科手術を受けた患者の術後疼 痛の経時的経過と, 患者の個人的背景が術後疼痛の程 度および経過にどのように影響しているかを明らかに した，患者を取り巻く個人特性や治療特性によって痛 みがどのように影響を受けるか, 術後の経過に伴って どのように痛みが変化するかを明らかにしたことで, 術後疼痛に予測的にかかわり, 連鎖的に回復遅延につ ながる痛みの悪循環（林田ら，2004）を断ち切ること に貢献できる.

本研究の結果からは, 術後, 患者に生じる疼痛が術 後 4 時間をピークとして経過し, 65 歳未満の患者, 術前に何らかの術後リスク要因を有していた患者, 独 居者, 手術時間が長い患者, 術後のルート類が通常よ り多く挿入されている患者の術後疼痛が強い傾向にあ ることが示された．とくに同居者の有無，ルート類の 数による術後疼痛の経過は，年齢および手術時間を調 整し他の要因の影響を考慮しても同じ結果であり,こ れらが術後疼痛の程度や経過に影響していることが明 らかになった。

65 歳未満の患者より前期・後期高齢者のほうが, 術後疼痛が少なく経過するという結果については, 加 齢による知覚鈍麻や神経伝達遅延などの生理的老化,
精神活動の低下（社団法人日本老年医学会, 2002）が 疼痛の過小評価になっていると考えられるほか, 認知 力の低下した高齢者がNRS で疼痛を表現することの 難しさと, 表現された数值の妥当性をバイタルサイン や表情, 行動など他の指標から十分にアセスメントさ れないまま（鈴木ら，2014）看護師が記録していた可 能性がある。一方, 豊かな人生経験のなかで, トー夕 ルペインとしてさまざまな苦痛体験とそれを乗り越え る経験を有し, 苦痛への心理的準備や対処方法を体得 していることが高齢者の疼痛閾值を高めているとも考 えられる。 これに対し，比較的若い患者の場合には術 後疼痛が強く経過することが予測されるため, 術前か らの疼痛管理オリエンテーションの強化や術後の頻回 な疼痛アセスメントを検討する余地がある。ただし， 高齢者の場合にもそれだけで短絡的に疼痛閾值が高い と判断することは避けなくてはならない。 むしろ, 年 齢が術後疼痛に影響する背景に, 認知レベルや身体機 能の経年的変化，それまでの疼痛体験が影響している と考え, 慎重な疼痛アセスメントが必要であることは 言うまでもなく，長い人生において経験したであろう 本人や家族の手術歴や配偶者との死別状況，地域や家 庭での人間関倸やストレス等による苦痛体験やその受 け止め, 対処方法などを十分に聴取し, 術後疼痛への 影響を判断する必要がある。

また本研究では, 同居者のいる患者のほうが, NRS 
が低く経過する傾向が示された，本研究では, 術後疼 痛を術式や創部位，ドレーンの位置などの身体面だけ でなく, 患者の性格や過去の体験による手術への思い, 安楽な環境や家族によるサポート体制, 予後への不安 などの心理・社会的要因やスピリチュアルな側面から も影響を受ける全人的苦痛（トータルペイン）である ととらえている，とくにサポート体制という側面から みると, 患者と良好な関係にある同居者の存在は, 術 後疼痛に直面している患者の心理的な支えとなり，そ の後の術後生活の再獲得を支える存在として安堵感を もたらし患者の苦痛緩和に大きく貢献すると考えられ る.このことは, 術直後からの家族のサポートが患者 の疼痛軽減や治癒促進, 回復意欲を支えることに効果 的である（青山ら，2008／小林，2017）との報告と も合致する. また, 心疾患や整形外科手術を受け退院 した患者の QOL を調査した研究（島田ら，2018）（木 下ら，2015）では，患者は退院後の疾患や病態の悪化， および日常生活への制限に対する心配や困りごとがあ るが, 同居者のいる患者は独居者に比べ有意に身体面, 社会面, 感情面の QOL が高いことが示されている. 患者一人では対処できない日常生活上のサポートを同 居者に委ねられる安心感が患者の QOL に影響してい ると考えられるが，これと同様に，自分では対処する 術がない術後疼痛に直面した患者にとって, 術後のサ ポートを委ねられる同居者がそばにいることで安堵し 苦痛の軽減につながると考えることは妥当である。ま た, 同居者の存在は入院患者の睡眠の質にも影響し (Park・Kim, 2017), 術後の安静期間に生じる苦痛を 乗り越えるための精神的な支えになっている(加納ら， 2017）ことも報告されている. 手術当日の夜は患者に とって身体的にも精神的にも非常につらい時間帯であ るが, 精神的支えとなる同居者がいるという安心感か ら術後の安眠を得て生活リズムの安定が図れ，翌日の 積極的な離床行動につなげられるとも考えられる.こ れらの報告は, 回復への支えとなる同居者の存在が, 手術を受ける患者の不安や焦りなどの心理的苦痛を和 らげ，身体的苦痛の軽減にも連鎖的に関連することを 示唆し, 術後疼痛をトータルペインと考える本研究の 結果を支持するものである. 本研究では同居者の有無 以外には, 面会状況や患者との関係性まで調査をして いない. しかし, 手術当日は多くの術後患者に面会が あり，とくに同居家族のいる患者は，遠慮なく痛みを 表出し相談する相手が術後そばにいる環境であること
が多い. 同居者のいる患者は, その存在への安心感は 当然のことながら, 疼痛への対処や要望をナースコー ル以外の手段で夕イムリーに医療者に伝える代弁者が 身近にいることも, 術後疼痛が増強せずに経過できた 要因の一つであると考える. 今後は術後患者の疼痛軽 減と社会的サポートの関連性に焦点を当てた継続研究 によって, 患者の心理的安寧からさらなる術後疼痛の 軽減が図れる可能性がある。これらのことから, 周術 期看護に押いては, 家族や同居者等, 手術を受けた患 者の支えとなる人が負担なく患者のそばにいることが できる環境を作り, 同居者による付き添いがない場合 でも, 看護師が患者との信頼関係の下でこれらの役割 を代替することが, 術後疼痛の軽減を図るために必要 である。

次に, 本研究では, 術前評価にて運動機能や循環機 能, 腎機能, 呼吸機能等, 何らかの術後リスク要因を 有している患者の術後疼痛が高くなる傾向を示した. このことについて, 例えば術前から腰痛のある患者が, 術後長時間の臥床によって疼痛を訴えること, あるい は術前の呼吸機能検查で一秒率の低い患者が, 術後, 痰喀出が困難となり創痛が増強すること, または吸引 等の苦痛処置を受けることで二次的に痛みが発生する ことは臨床的にも妥当なことである.つまり, 術後り スク要因をもつ患者は, その身体的特性から術後疼痛 が増強する可能性が十分に考元られるが, 本研究では そのことを客観的に明らかにしている.ささらに本研究 では, 手術時間が長い患者のほうが, 術後疼痛が強い 傾向を示した. 手術時間が長い分, 手術侵襲も大きく なることは容易に予測できるが，術後疼痛が増強する ことも意識する必要がある．とくに，術前評価にて術 後の合併症等のリスク要因があると判断される患者 は，それぞれの機能低下に追随する疼痛リスクの増強 だけでなく，それに付随する手術時間の延長から術後 疼痛が増強することを予測してかかわることが必要で ある.

さらに, 術後に複数の術後ドレーンや中心静脈カ テーテルなどが挿入されている患者においては, 術後 疼痛のピークを過ぎてからも疼痛の軽減がみられず経 過するという特徴的な経過を示した。この特徵がみら れるタイミングが, 術後, 麻酔覚醒し体動が増すころ から本格的に離床を開始する翌日にかけての時間带で あることから，通常より多いルート類による離床の妨 げや, ルートの過緊張やねじれ, 固定状況による痛み 
の増強, ルート類を意識した行動による筋の過緊張を 招いていることが考えられる，そのため，術後ルート が通常より多く扦されている患者に対しては，とく に，離床による急激な術後疼痛の出現と継続を予測し てかかわる必要が示唆される，なお，術後ルート類を 変数とした分析では，複数ルート類が抻入されている ことにより疼痛が増強していることも考えられるた め, 因果関係を考える根拠にはならない.

最後に, 本研究では今回, 患者の年齢や世带構成, 術前リスク要因や手術時間, 術後扦入ルートなどの限 られた関連要因のみを術後疼痛の影響要因として取り 上げ，術後疼痛の経過との関連を検証したが，今回検 証に及んでいない要因もまだ多く存在する（Tighe et al, 2015) (Kannampallil et al, 2016 / Chapman et al, 2011). そのため, 術後疼痛に予測的にかかわるため には, 患者の年齢や生活状況, 過去の疼痛体験, 医療 者のかかわりなど, 患者を取り巻く何気ない情報の一 つひとつが術後疼痛の程度や経過に影響する要因であ る可能性を意識することが術後疼痛を増強させないか かわりとして重要である.

本研究の限界として, 今回疼痛スケールとして使用 したNRS は患者の主観的評価であるため, 分析に至 る前の段階で患者の術後疼痛をどこまで厳密に反映で きているか, その妥当性には課題が残る. また疼痛時 鎮痛薬指示も比較的画一的で疾患や術式が限定される なかでのデー夕分析であるため, 他の疼痛時鎮痛薬指 示や術式によって疼痛の経過が変動することが考えら れる.ささに, 本研究では痛みの経過を術後疼痛のピー クとされる 24 時間のうち, 8 時点に限定し, なるべ く離床や生活範囲の拡大による影響を受けない期間に 限定してデー夕収集したが，実際には術後 1 日のうち にも離床が進み，睡眠や活動などにも影響を受けた NRS の数值である可能性もあり研究の限界といえる. また本研究は, 一般化された推定結果であるという分 析の性質上, 対象患者の個別的な術後疼痛の差異をと らえきれるものではないが, 術後疼痛の経過を経時的 に観察し，患者のもつ個人要因のばらつきも考慮して モデル化した研究はほかにない，そのため今後は，よ り多くの施設において看護師のかかわりも要因に含め たさまざまな疼痛関連状況を含めて分析を進めること で, 予測的な術後疼痛緩和への一般化した示唆を示す ことができ，周術期看護の質向上に貢献できると考え る.

\section{VII. 結語}

1. 術後患者の術後疼痛は帰室後 4 時間をピークとし て経過する。

2. 65 歳未満, 独居者, 術前に何らかの術後リスク要 因があると判断される患者, 手術時間の延長, ルー 卜類が通常より多い患者は術後疼痛が強く経過す る傾向にある。

3. 術後疼痛に予測的にかかわるためには，患者を取 り巻く何気ない情報の一つひとつが術後疼痛の程 度や経過に影響する要因である可能性を意識する ことが重要である.

\section{付記}

本研究は, 山梨県立大学看護学部より 2015 年度共 同研究費助成を受けて実施し, 第 36 回日本看護科学 学会学術集会において発表したものである.

\section{利益相反}

本研究において著者が報告すべき利益相反（COI） は存在しない.

\section{謝辞}

本研究を実施するにあたり，ご理解とご支援を賜りました 協力施設の病院長, 外科医師の皆様, および看護局長, 対象 病棟の看護師の皆様方に深く御礼を申し上げます。また，調 查依頼の際に, 今後の術後疼痛管理の向上を切望し, 快くご 協力くださったすべての患者様とそのご家族の皆様方に心よ り感謝申し上げます。

文献

青山みどり, 清水理恵子, 杉山亜希子(2008). 心臓手術患者 の術後急性期の看護支援に関する研究一安楽の変調 (疼 痛)軽減に焦点を当てて，看護技術，54，1543-1549.

Chapman CR, Donaldson GW, Davis JJ, et al. (2011). Improving individual measurement of postoperative pain: the pain trajectory. J Pain., 12, 257-262.

Chapman CR, Zaslansky R, Donaldson GW, et al. (2012). Postoperative pain trajectories in cardiac surgery patients. Pain Res Treat., 2012, 608359.

Cleeland CS, Ryan KM. (1994). Pain assessment: global use of the Brief Pain Inventory. Ann Acad Med Singapore., 23(2), 129138.

Douglas AL. (2004). Multilevel Modeling (Quantitative Applications in the Social Sciences). 62-72, California: SAGE Publications, INc.

Fearon KC, Ljungqvist O, Von Meyenfeldt M, et al. (2005). 
Enhanced recovery after surgery: a consensus review of clinical care for patients undergoing colonic resection. Clin Nutr., 24, 466-477.

福田美和子 (2007). ICUにおける熟練看護師の看護実践の様 相一第1部：心臓外科手術後の変化過程への対応場面に焦 点を当てて. 日本クリティカルケア看護学会誌, 3(2), 83-92.

林田眞和, 藤本幸弘, 花岡一雄 (2004). 術後痛の成因, 花岡 一雄 (編), 術後痛. 3-18, 東京: 克誠堂出版.

Hox JJ, Kreft IGG. (1994). Multilevel Analysis Methods. Sociological Methods \& Research., 22, 283-299.

井川由貴, 遠藤みどり, 山本奈央 $(2013)$. 術後疼痛管理の実 践に影響を及ぼす看護師の疼痛体験と学習経験一マルチ レベルモデルを用いたデータの分析. 日本クリティカル ケア看護学会誌, 9(3), 24-33.

Kannampallil T, Galanter WL, Falck S, et al. (2016). Characterizing the pain score trajectories of hospitalized adult medical and surgical patients: a retrospective cohort study. Pain., 157, 27392746.

加納実希, 境高志, 久保孝 (2017). 腰椎手術後の安静期間を 乗り越えた患者の精神的支えになったもの. 東邦看護学 会誌, $14(2), 17-25$.

木下美樹, 吉田俊子, 山田嘉明, 他 (2015). 人工股関節全置 換術を受けた患者のQOLの変化と関連要因の検討. 日本 看護研究学会雑誌, 38(5), 61-72.

小林礼実(2017). 心臓の緊急手術を受けた患者の回復意欲の 構造. 日本クリティカルケア看護学会誌, $13(3), 113-122$.

厚生労働省 (2002). 平成14年患者調查の概沉 (2002). Retrieved from : https://www.mhlw.go.jp/toukei/saikin/hw/kanja/02/ index.html(閲覧日：2019年1月25日)

厚生労働省 (2011). 平成23年 (2011) 患者調查の概況. Retrieved from : https://www.mhlw.go.jp/toukei/saikin/hw/kanja/11/ index.html(閲覧日：2019年1月25日)

Kreft I, de Leeuw J. (1998) / 小野寺孝義, 岩田昇, 菱村豊, 他 (2006). 基礎から学ぶマルチレベルモデル一入り組んだ文 脈から新たな理論を創出するための統計手法. 9-10. 京 都：ナカニシヤ出版.

Maruo T, Nakae A, Maeda L, et al. (2013). Translation and reliability and validity of a Japanese version of the revised ShortForm McGill Pain Questionnaire (SF-MPQ-2), PAIN RESEARCH., 28(1), 43-53.

Park MJ, Kim KH. (2017). What affects the subjective sleep quality of hospitalized elderly patients? Geriat Gerontol Int., 17, 471-
479.

Payen JF, Bru O, Bosson JL, et al. (2001). Assessing pain in critically ill sedated patients by using a behavioral pain scale. Crit Care Med., 29, 2258-2263.

Roulin D, Donadini A, Gander S, et al. (2013). Cost-effectiveness of the implementation of an enhanced recovery protocol for colorectal surgery. Br J Surg., 100, 1108-1114.

Sasaki K, Tamakoshi K. (2018). Association between the perspective of adult inpatients with digestive cancer regarding the nursing service and their quality of recovery on postoperative day 3 . Nagoya J Med Sci., 80(1), 29-37.

社団法人日本老年医学会(編) (2008). 老年医学テキス卜. 改 訂第3版, 7-11, 東京 : メジカルビュー社.

柴裕子, 松田好美 (2014). 開腹術後患者における早期離床を 促進する看護師の判断プロセス. 日本看護研究学会雑誌, $37(4), 11-22$.

Shida D, Wakamatsu K, Tanaka Y, et al. (2015). The postoperative patient-reported quality of recovery in colorectal cancer patients under enhanced recovery after surgery using QoR-40. BMC Cancer., 15, 799.

島田詩絵奈, 小野加奈, 佐藤三穂 (2018). 心疾患患者の退院 後における QOLに影響する要因の検討. 看護総合科学研 究会誌, 18(2), 29-36.

Spanjersberg WR, Reurings J, Keus F, et al. (2011). Fast track surgery versus conventional recovery strategies for colorectal surgery. Cochrane Database Syst Rev., (2), CD007635.

Suzuki K, Sato M, Zheng W, et al. (2015). Childhood growth trajectories according to combinations of pregestational weight status and maternal smoking during pregnancy: a multilevel analysis. PLoS One., 10(2), e0118538.

鈴木みずえ, 古田良江, 高井ゆかり, 他 (2014). 認知症高齢 者における疼痛の有症率と疼痛が認知症の行動・心理症 状 (BPSD)に及ぼす影響. 老年看護学, 19(1), 25-33.

高島尚美, 五木田和枝 (2009). 在院日数短縮に伴う消化器外 科系病棟における周手術期看護の現状と課題一全国調查 による病棟看護管理者の認識. 日本クリティカルケア看 護学会誌, 5(2), 60-68.

Tighe PJ, Le-Wendling LT, Patel A, et al. (2015). Clinically derived early postoperative pain trajectories differ by age, sex, and type of surgery. Pain., 156, 609-617.

Twisk JWR. (2006). Applied Multilevel Analysis: A Practical Guide for Medical Researchers. Cambridge: Cambridge University Press. 


\section{Abstract}

Purpose: It is commonly believed that individualized care for patients with postoperative pain is very important. The purpose of this study was to clarify the trajectories of postoperative pain scores (Numerical Rating Scale; NRS) of patients and their factors, and to elucidate methods for perioperative pain management as preventive measures.

Method: We performed analysis via the generalized linear mixed model to evaluate the NRS with 50 patients who underwent digestive surgery ward as objective variables and with sociodemographic data and surgical status as explanatory variables.

Results: Of all participants, 20 (42.5\%) were female, 27 (57.5\%) were male, mean age was $67.4 \pm 14.2$, and $33(70.2 \%)$ lived with family. Over half of participants have several postoperative risk factors leads to some kinds of complications during preoperative examination. The mean operative time was $213.6 \pm 93.9$ minutes. Fourteen patients (29.8\%) required more fluid replacement or catheters than usual. The peak of postoperative pain was 4 hours postoperatively $(\mathrm{p}=0.0083)$. Patients who were under 65 years old $(\mathrm{p}=0.0771)$, lived alone $(\mathrm{p}=0.0463)$, had longer operative time $(\mathrm{p}=0.0219)$, and had a greater number of catheters $(\mathrm{p}=0.0544)$ tended to have worse postoperative pain.

Discussion \& Conclusion: In order to take a predictive approach to perioperative pain management, we should be conscious of how postoperative pain is affected by patients' characteristics, including preoperative status. Moreover, we should propose individualized care that includes the patient's postoperative condition as a factor that influences postoperative pain. 